\title{
STAPELIA HIRSUTA.
}

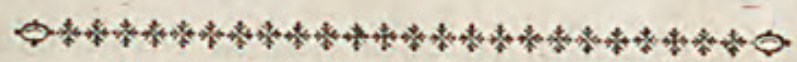

\section{CHARACTER GENERICUS.}

Corolla contorta.

Nectarium ftellula duplex in medio corollæ.

Pentandria Digynia.

CHARACTER SPECIFICUS, Eंc.

STAPELIA denticulis ramorum erectis.

Lin. Spec. Plantar. p. 316.

ASCLEPIAS AFRICANA AIZOIDES, flore pulchre fimbriato.

Comm. rar. 19. t. 19.

Inter pretiofifimas plantarum dotes merito numeratur odor ille gratiffimus quem plurimæ emittunt, quo in colligendo, confervando, augendo, fubtiliter ftudiofeque femper laboratum eft. Suave-olentium vegetabilium tanta fane eft diverfitas, ut odores fpeciatim recenfere vix poffibile fit. Ut taceam rofam, violam, dianthum, cæteramque copiam narium in hortis plerifque repertam, genera Diofmæ, Illicii, Nyctanthes, et Polyanthes, velut exempla fuaviffma et pollentiffimæ fragrantiæ fatis fit proferre.

Huic aromaticorum ubertati opponuntur exempla aliquot contrarii odoris in generibus Ari, Sterculix, Lobeliæ, cæterifque nonnullis; rara hæc quidem, quæ tamen fatis probant Naturam in humani generis oblectatione 
lectatione non femper verfari. Phalli fpecies, in fylvis, exeunte $æ$ ftate, non raro confpecta, odorem quafi carnis putridæ fpargendo, infecta multa carnivora, mufcas præcipue vulgares, feu carnarias ad fe allicit, quæ in fummitate plantæ catervatim conglomerantur, liquorem glutinofum exinde copiofe effluentem avidiffime exugentes.

Omnes autem hactenus cognitas, quæ more mortui cadaveris fætere folent, planta illa in tabula depicta longe fuperat; cui tanta eft odoris putridi graveolentia, ut e longinquo veniant mufcæ vulgares feu carnariæ LINNAI, ovaque ibi deponant; quibus exclufis, larvæ parvo tempore plerumque pereunt; qua in re unica feipfam decipere, fuaque quafi fruftrare confilia videatur Natura. Interdum tamen, fi qua fides obfervatoribus, accidit ut aliæ mufcarum rpecies, carnaria multo minores, in eodem flore ova fua deponant, larvæque exclurie, ob exiguitatem parvo cibo egentes, forem ipfum depafcant; ad plenam magnitudinem perveniant, et in chryfalides convertantur, ex quibus mufcæ perfectæ poftea erumpunt. Ita fe rem habere demonftrat experimentum a domino Hir.L memoratum, qui narrat larvas plurimas mufcarum, hoc folo flore enutritas, omnibus vicibus et permutationibus abfolutis, ad plenam et perfectam maturitatem adoleviffe.

Africæ eft indigena hæc planta, et in promontorio bonæ fpei præcipue invenitur. 


$$
4
$$




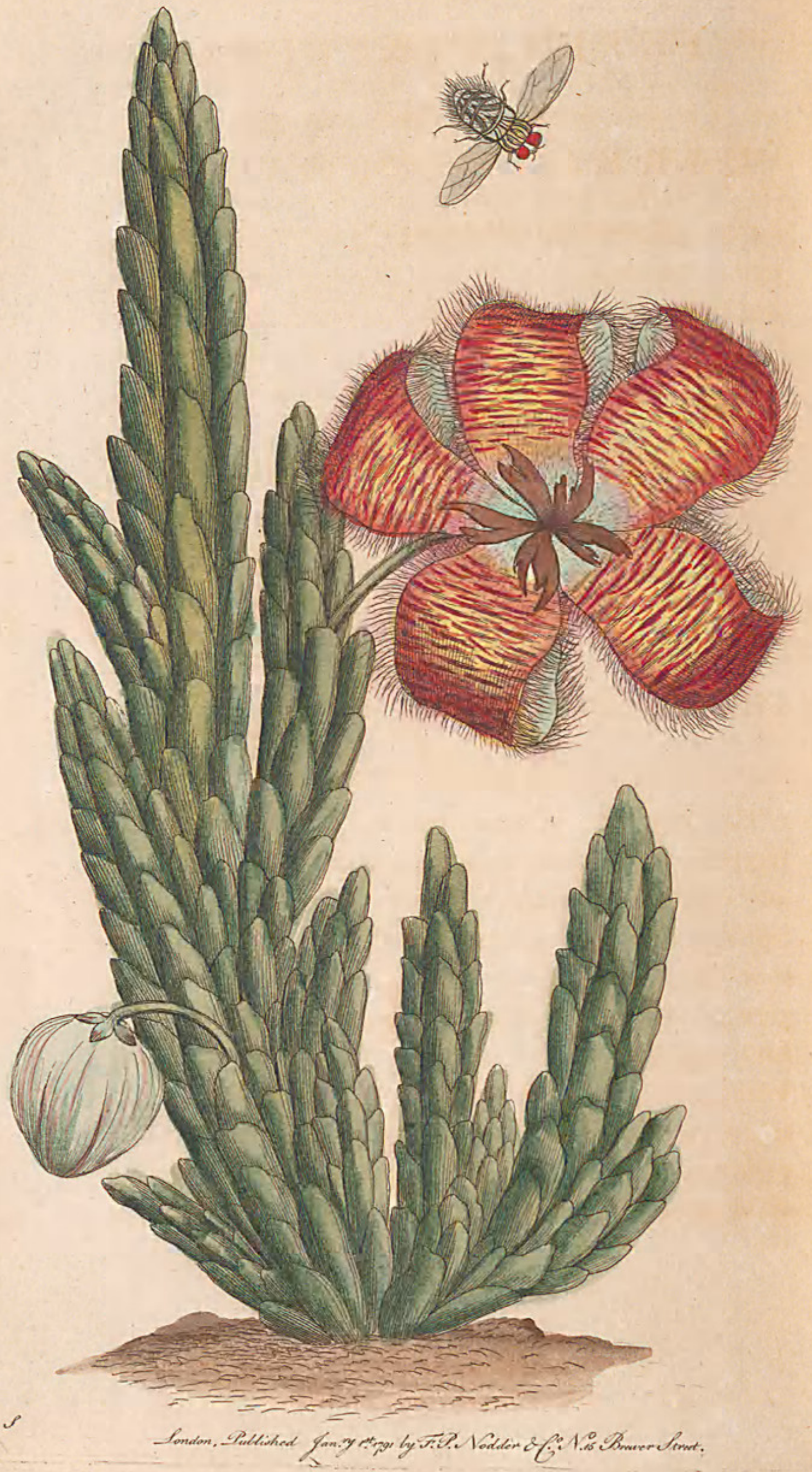




\section{FETID STAPEIIA, \\ O R T H E \\ CARRION-FLOWER.}

Q

\section{GENERIC CHARACTER.}

Corolla flightly twifted towards one fide. Nectary in form of a double ftar in the middle of the corolla.

\section{Pentandria Digynia.}

SPECIFIC GHARACTER, छัC.

STAPELIA with the denticles of the branches upright.

THE CARRION-FLOWER.

The fragrance emitted by the major part of the vegetable world is fuch as to be regarded amongft the moft elegant and valuable attributes of plants; and the ingenuity of mankind has been ftudiounly employed in collecting, preferving, and concentrating it. So great is the variety of vegetable perfumes that it is hardly poffible to enumerate the different kinds. Without particularizing the rofe, the violet, the carnation, and many other common inhabitants of the garden, we might adduce the genera of Diofma, Illicium, Nyctanthes, Polyanthes, and fome others, as peculiar 
peculiar examples of the richeft and moft exalted fragrance.

Amidf this profufion of fwects in the vegetable kingdom there are occafionally interfperfed fome examples of a contrary odor: thus fome fpecies in the genera of Arum, Sterculia, Lobelia, and a few others, are convincing proofs that Nature does not always accommodate her productions to the immediate gratification of the human fenfe.

A fpecies of Morell, not uncommon in woods towards the latter part of the fummer, has a fmell fo much refembling that of putrid animal matter, as to attract feveral fpecies of carnivorous infects, and particularly flies, which are generally obferved fettled in great numbers on the top of the plant, and eagerly feafting on the glutinous moifture with which it abounds.

But of all vegetables yet known, which are poffeffed of a fmell fimilar to that of animal fubftances, the plant here figured is by far the moft remarkable; and when in a fate of florefcence, diffufes a fcent fo powerfully cadaverous as to allure the common flefh-fly, or blow-fly to depofit its eggs on the flower, where they are hatched, and the young larvæ, for want of proper nutriment, commonly perifh foon afterwards; and thus Nature in this fingle inftance, almoft feems to have deceived herfelf. If however we may rely on fome obfervations, it happens fometimes that other fpecies of files much fmaller than the common flefh-fly, depofit their eggs in the flower, and when hatched, the larvæ being verv fmall, and not requiring much food, 
do actually find a fufficient nutriment from the flower itfelf, till the time of their change to chryfalis arrives; and after the ufual period become complete flies; and this appears to have been the cafe in an inftance recorded by the late Sir John Hill, where feveral larvæ of flies are faid to have paffed through all their changes, though nourifhed folely by the flower of this plant.

It is a native of Africa, and is principally found at the Cape of Good Hope. 


\section{$2 \mathrm{BHL}$ Biodiversity Heritage Library}

Shaw, George. 1791. "Fetid Stapelia or the Carrion - Flower, Stapelia hirsuta [PI. 54]." The Naturalist's Miscellany 2(XIX), https://doi.org/10.5962/p.310706.

View This Item Online: https://www.biodiversitylibrary.org/item/276232

DOI: https://doi.org/10.5962/p.310706

Permalink: https://www.biodiversitylibrary.org/partpdf/310706

\section{Holding Institution}

Museums Victoria

\section{Sponsored by}

Atlas of Living Australia

\section{Copyright \& Reuse}

Copyright Status: Public domain. The BHL considers that this work is no longer under copyright protection.

This document was created from content at the Biodiversity Heritage Library, the world's largest open access digital library for biodiversity literature and archives. Visit BHL at https://www.biodiversitylibrary.org. 